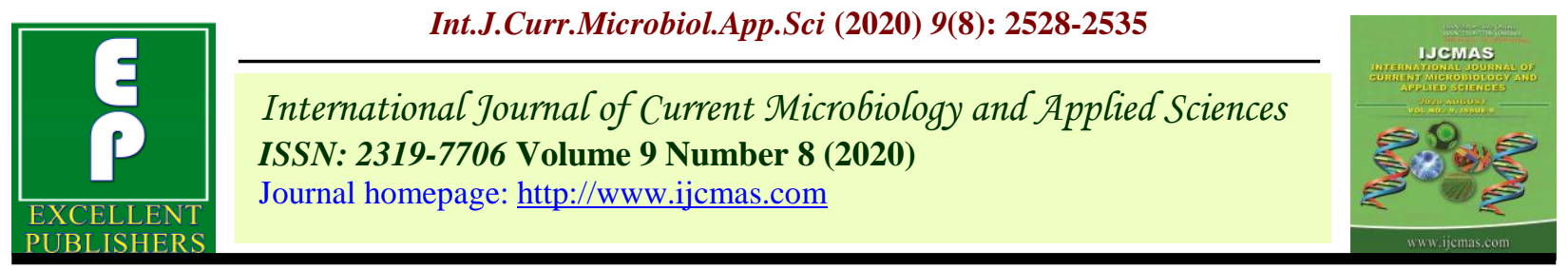

Original Research Article

https://doi.org/10.20546/ijcmas.2020.908.290

\title{
Milk Fat Globule Size, Distribution and Somatic Cell Count of Indigenous Goat Breeds in Kerala
}

\author{
M. Sudharsan ${ }^{\text {** }}$, A. Kannan', K. S. Anil ${ }^{1}$, Justin Davis ${ }^{1}$, \\ K. Ratha ${ }^{2}$ and S. Dhinesh Kumar ${ }^{1}$
}

${ }^{1}$ Department of Livestock Production Management, ${ }^{2}$ Department of Dairy Science, College of Veterinary and Animal Sciences, Mannuthy, Thrissur, Kerala - 680 651, India

*Corresponding author

\section{Keywords \\ Milk, Fat globule size, Distribution, SCC, Lactation stage, Attappady Black, Malabari, Goats \\ Article Info \\ Accepted: \\ 22 July 2020 \\ Available Online: \\ 10 August 2020}

\section{A B S T R A C T}

\section{Introduction}

The Attappady black goat has its origin from the Attappady hills of Western Ghats which is located in the north eastern part of Palakkad district in Kerala. This region is inhabited by the major tribal communities of the State known as Irulas, Mudukas and Kurumbas. The tribal economy and development is mainly dependent on goat rearing and associated agricultural activities. Attappady black goats are medium sized, lean slender bodied and black in colour. They have bronze colour eyes and black horns with curved backward oriented tips. The ears are black, pendulous and the tail is curved and bunchy. Milk production of Attapady black goats ranges from 200-400 $\mathrm{ml}$ per day and is prolific meat purpose breed. The Malabari goats are mainly reared in the Malabar region of kerala. They are medium to small sized animals having various goat colours from white to admixtures and black with an average milk yield of 0.5 to 1 litre/ day. One of the main constituent of milk fraction is fat. In the last few years, knowledge of the milk composition and properties of the milk fat globule size had increased significantly 
(Stahy and Argaman 2014). Because the milk fat globule size plays a major role in nutritional value and technological properties of dairy products to churning of cream, cheese making and separation of fat. Fat globule size also determines the optical and rheological properties, emulsion stability of product and protein absorption per unit area(Hoda and El-Zeini, 2006). Goat milk has better digestibility because of the lower curd tension in goat milk (Puri et al., 1952). The creaming rate is important in milk and milk products while processing and the creaming rate is lesser in goat milk rather than in bovine milk because of smaller fat globules (Parkash and Jenness 1968).Total fat content and fat globule size distribution affects the viscosity of milk and has an application in the processing and manufacture of milk products.

Milk fat is secreted from the mammary gland epithelial cells and the structure called as milk fat globules (MFG). Triglycerides present in the ER and are released to the cytoplasm with covered by mono layer of phospholipids (Keenan and Mather, 2002) then the lipid droplets migrate to alveolar lumen and it's covered by an apical cell membrane bilayer. The polar lipid envelop of the triglyceride droplet is termed as MFG membrane. Normally the fat globule size of goat milk is lower than cow milk because of its natural homogenising property of milk. The lower diameter of fat globules is mainly used to the milk processing unit because of low energy consumption is enough for the separation the fat and is faster than the cow milk and the creaming rate is lower in goat milk than the bovine milk because of apparently absence of agglutinin process of goat milk (Attaie et al., 2000) for this reason the goat milk has a better digestibility than the dairy cattle. In addition to that, demand of goat milk arrives from suffering of peoples with cow milk allergy and other gastro intestinal problems. This demand is also increasing due to greater awareness of peoples with traditional medical remedy. Goat milk composition is differing from other mammalians milk, it having the better digestibility, alkalinity, buffering capacity and certain therapeutic values. Fat globule size of the milk can vary with various lactation stages are reported by several researchers (Kuchroo and Narayanan et al., 1977, Carriquiry et al., 2009, Stahy et al., 2014).Mastitis is an animal welfare problem as well as important production disease of dairy industries and results in severe economic loss by reducing milk production, physical, chemical and hygienic quality of milk and increasing cost of treatment (De Vliegher et al., 2005). Sub-clinical mastitis is important due to the fact that it is $15-40$ times more prevalent than the clinical mastitis form, is of long duration, difficult to detect, adversely affects milk quality and production (Schultz et al., 1978). Somatic cell count (SCC) is the indicators of mastitis and subclinical mastitis at both herd level and individual goats (Droke et al., 1993). SCC has become a gold standard measure of milk quality (Reneau, 2001). The Somatic cell count is a useful predictor of intra mammary infection which consists of milk secreting epithelial cells that have been shed from the lining of gland (25\%) and leucocytes $(75 \%)$. The current goat milk SCC standard is $1 \times 10^{6}$ cells/ml. (Droke et al., 1993). Normally goat milk had a higher SCC than the cow milk because of the milk secretion, apocrine in the goat versus merocrine in the cow. This leads to higher content of non leukocytic, cell like fragments in the goat milk. Moreover SCC has significant negative impact on both milk yield and chemical composition of milk. (Dulin et al., 1982, Das et al., 2000, Petlane et al., 2012, Bravoa et al., 2013, Yarabbi et al., 2014, Cinar et al., 2015). These problems can be avoided by regular analysis of milk for somatic cell count and the other factors which affect milk composition. 


\section{Materials and Methods}

\section{Location of the study}

The research was carried out in the ex-situ conservation units of Attappady black goats in Kerala Veterinary and Animal Sciences University. The units are, University Goat and Sheep farm, College of Veterinary and Animal Sciences, Mannuthy. The station is located at longitude of $76^{\circ} 15^{\prime} \mathrm{E}$ and latitude of $10^{0} 31^{\prime} \mathrm{N}$ and at altitude of $30 \mathrm{~m}$ above the sea level and Livestock Research Station, Thiruvazhamkunnu which is located at longitude of $76^{\circ} 36^{\prime} \mathrm{E}$ and latitude of $11^{\circ} 03^{\prime} \mathrm{N}$ and at altitude of $35 \mathrm{~m}$ above the sea level.

\section{Management}

Animals were maintained under semiintensive method with morning hours (6h) grazing and feeding seasonally available green fodder with concentrate mixture at the rate of $500 \mathrm{~g}$ day. The study was conducted for a period of seven months from October 2016 to April 2017.

\section{Sample analysis}

Milk samples (10ml) from individual goats were collected first at seventh day of lactation then every three weeks interval of the does till the end of lactation from November 2016 to March 2017 during morning milking to study the fat globule size, distribution and SCC. Totally 120 Attappady black and 60 Malabari milk samples were collected in this study. Milk samples were collected in clean and sterile plastic container from individual animal by hand milking. For analysing fat globule size, the milk sample of $1 \mathrm{ml}$ was diluted to $10 \mathrm{ml}$ with distilled water. The diameter of fat globules was measured as per Rangappa (1964) by using ocular micro meter, the scale of which being previously determined by a $1 / 100^{\text {th }}$ stage micrometer.
The average diameter was obtained by multiplying the number of globules in each group by its group average, summing the products and dividing it by the total number of globules in all groups as per Kuchroo and Narayanan (1977). Somatic Cell Count was estimated using DeLaval somatic cell counter. The DeLaval cell counter (DCC, DeLaval International $\mathrm{AB}$, and Tumba, Sweden) is a portable, battery-operated optical cell counter that determines the SCC. Milks were analysed at room temperature as per DCC instruction manual. A cassette containing the fluorescent stain propidium iodide is used to collect the milk prior to cell counting. A predetermined volume of milk was drawn up into the singleuse cassette.

The cassette was placed in the machine and the machine set to run. The sample is carried by a piston toward the counting window, where it is exposed to a light-emitting diode. The fluorescent signals produced by the stained cell nuclei are recorded as an image. The DCC was designed for SCC determination using raw bovine milk (DeLaval, 2005). Optimization of the DCC for goat milk (Berry and Broughan, 2007) revealed a high correlation (95\%) with direct microscope cell counts. The result indicates the number of cells $/ \mathrm{ml}$ of milk and this was multiplied by 1000 to give cells $/ \mathrm{ml}$ of milk. The range of the cell counter was 10000$4000000 \mathrm{cells} / \mathrm{ml}$. Only one value per milk sample was obtained using DCC. No preservative was added as per instruction book for the DCC (DeLeval, 2005) all goat milk samples were charged in the cassettes with a 1-minute soak time prior to analysis.

\section{Statistical analysis}

Data obtained on the experiment were subjected to statistical analysis as per Snedecor and Cochran (1994) and results were interpreted. 


\section{Results and Discussion}

The milk fat globule size of Attappady Black and Malabari goats during different stages of lactation were represented in Table 1 and the microscopic structure of milk fat globules were illustrated in Plate1. The mean diameter of fat globule size in Attappady Black and Malabari goats were 2.83 and 2.94. The results obtained were similar to George (1981) who stated the milk fat globule size of Sannan x Malabari goats were $2.70 \pm 0.03 \mu$. Similarly Attaie and Richtert (2000) who reported the individual fat globules of goat milk ranged from $0.73-8.58 \mu$. In contrary to the results, Narangerel et al., (2016) reported the average size of fat globules in Mongolian goat milk was $2.43 \pm 0.12 \mu$. Similarly, Venkatachalapathy and Iype (1997) reported theaverage milk fat globule size of Malabari cross breed was 2.60 which was lower than the present findings.The higher size fat globule size was noticed in the $4^{\text {th }}(3.88 \mu)$ and $7^{\text {th }}(3.69 \mu)$ week of lactation in Attappady Black and Malabari goats respectively and the smaller size fat globules was noticed in the $10^{\text {th }}(2.01 \mu)$ and $16^{\text {th }}(2.26$ $\mu$ ) week of lactation in Attappady Black and Malabari goats respectively. So, generally lower fat globule size was observed in late lactation of the goats. The present finding was in agreement with the results obtained by Venkatachalapathy and Iype (1997) who reported that the fat globule size is bigger in early lactation followed by mid and late lactation in Vechur cows. The fat globules size in early lactation was higher than the late lactation in cow milk which was reported byCarriquiry et al., (2009)and the similar observations have been reported by Stahy and Argaman (2014) whoreported the fat globules size was lower in late stage of lactation compared to early stage of lactation. The per cent distribution of fat globule size in Attappady Black and Malabari goats during different stages of lactation were documented in Table 2. The observation on the distribution of fat globules in different classes of $0-3,3-6$, and $6-9 \mu$ revealed that 75.245 , 21.01 and 4.97 per cent of fat globules respectively in Attappady Black and 64.98, 31.3and 3.43 per cent of fat globules in Malabari goats respectively.

Table.1 Milk fat globule size of Attappady Black and Malabari goats during lactation

\begin{tabular}{|c|c|c|c|c|}
\hline \multirow[b]{2}{*}{$\begin{array}{l}\text { Stages of lactation } \\
\text { (in weeks) }\end{array}$} & \multicolumn{2}{|c|}{ Fat globule size $(\mu)$} & \multirow[b]{2}{*}{ t-value } & \multirow[b]{2}{*}{ p-value } \\
\hline & $\begin{array}{l}\text { Attappady Black } \\
(\mathrm{n}=30)\end{array}$ & $\begin{array}{c}\text { Malabari } \\
(\mathrm{n}=10)\end{array}$ & & \\
\hline 1 & $2.50 \pm 0.11^{\mathrm{c}}$ & $2.36 \pm 0.13^{\text {ce }}$ & 0.689 & 0.495 \\
\hline 4 & $3.88 \pm 0.17^{\mathrm{a}}$ & $3.69 \pm 0.21^{\mathrm{a}}$ & 0.565 & 0.575 \\
\hline 7 & $2.93 \pm 0.12^{b}$ & $3.98 \pm 0.31^{\mathrm{a}}$ & $3.870^{* * *}$ & $<0.001$ \\
\hline 10 & $2.01 \pm 0.06^{\mathrm{d}}$ & $2.68 \pm 0.10^{\mathrm{bd}}$ & $5.764 * *$ & $<0.001$ \\
\hline 13 & & $2.64 \pm 0.20^{\mathrm{bc}}$ & & \\
\hline 16 & & $2.26 \pm 0.17^{\mathrm{de}}$ & & \\
\hline F-value & $56.070 * *$ & $19.891 * *$ & & \\
\hline p-value & $<0.001$ & $<0.001$ & & \\
\hline Mean & $2.83 \pm 0.09$ & $2.94 \pm 0.12$ & 0.727 & 0.468 \\
\hline
\end{tabular}


Table.2 The per cent distribution of fat globule size in Attappady Black and Malabari goats during lactation

\begin{tabular}{|c|c|c|c|c|c|c|}
\hline $\begin{array}{c}\text { Stages of lactation } \\
\text { (in weeks) }\end{array}$ & \multicolumn{3}{|c|}{$\begin{array}{c}\text { Attappady Black } \\
\text { (n=30) }\end{array}$} & \multicolumn{3}{c|}{$\begin{array}{c}\text { Malabari } \\
(\mathbf{n = 1 0})\end{array}$} \\
\hline & $0-3 \mu$ & $3-6 \mu$ & $6-9 \mu$ & $0-3 \mu$ & $3-6 \mu$ & $6-9 \mu$ \\
\hline $\mathbf{1}$ & 70.46 & 28.26 & 1.26 & 83 & 17 & 0 \\
\hline $\mathbf{4}$ & 65.26 & 21.86 & 12.86 & 44.8 & 48.2 & 7 \\
\hline $\mathbf{7}$ & 71.93 & 27.26 & 0.8 & 40.8 & 46.2 & 12.8 \\
\hline $\mathbf{1 0}$ & 93.33 & 6.66 & 0 & 67.8 & 31.4 & 0.8 \\
\hline $\mathbf{1 3}$ & & & & 69.8 & 30.2 & 0 \\
\hline $\mathbf{1 6}$ & & & & 85.2 & 14.8 & 0 \\
\hline Mean & 75.24 & 21.01 & 4.97 & 65.23 & 31.3 & 3.43 \\
\hline
\end{tabular}

Table.3 Somatic cell count of Attappady Black and Malabari goats during lactation

\begin{tabular}{|c|c|c|c|c|}
\hline \multirow{2}{*}{$\begin{array}{l}\text { Stages of lactation } \\
\text { (in weeks) }\end{array}$} & \multicolumn{2}{|c|}{ Somatic cell count (cells / ml) } & \multirow{2}{*}{$\begin{array}{c}\text { t- } \\
\text { value }\end{array}$} & \multirow[t]{2}{*}{ p-value } \\
\hline & $\begin{array}{c}\text { Attappady Black } \\
\qquad(\mathrm{n}=30)\end{array}$ & $\begin{array}{l}\text { Malabari } \\
(\mathrm{n}=10)\end{array}$ & & \\
\hline 1 & $48967.67 \pm 9485.44^{c}$ & $64500 \pm 15923.60^{c}$ & 0.825 & 0.415 \\
\hline 4 & $30033.33 \pm 7166.73^{d}$ & $45900 \pm 10885.71^{d}$ & 1.139 & 0.262 \\
\hline 7 & $85633.33 \pm 20568.61^{b}$ & $67200 \pm 14378.84^{c}$ & 0.500 & 0.620 \\
\hline 10 & $122100 \pm 23654.81^{\mathrm{a}}$ & $91600 \pm 21124.60^{b}$ & 0.709 & 0.482 \\
\hline 13 & & $107800 \pm 23576.26^{a}$ & & \\
\hline 16 & & $123800 \pm 26713.21^{a}$ & & \\
\hline F-value & $12.759 * *$ & $12.945 * *$ & & \\
\hline p-value & $<0.001$ & $<0.001$ & & \\
\hline Mean & $71683.33 \pm 8885.58$ & $83466.67 \pm 8398.80$ & 0.847 & 0.398 \\
\hline
\end{tabular}

Plate.1 Microscopic structure of milk fat globules

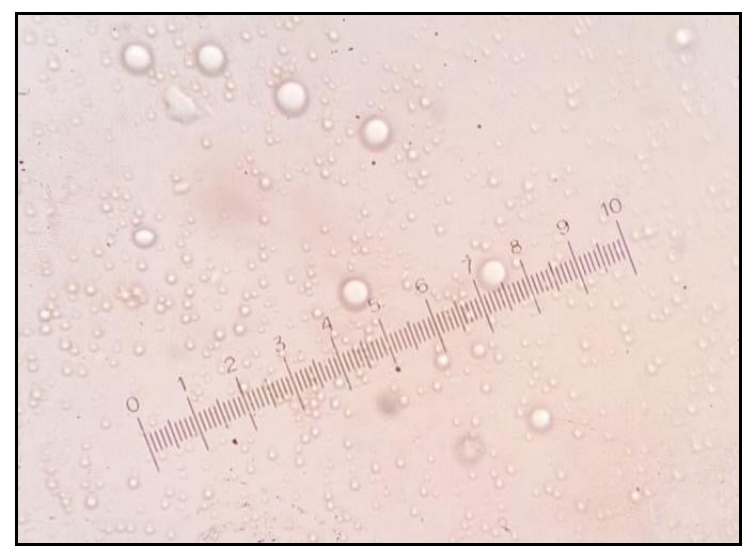


The proportion of 0-3 $\mu$ size fat globules was highly noticed in $10^{\text {th }}\left(93.33\right.$ per cent) and $16^{\text {th }}$ (67.8 per cent) week of lactation in Attappady Black and Malabari goats respectively. These findings are in accordance with the findings of George (1981) and Venkatachalapathy and Iype (1997).They reported the smaller size fat globule proportion was noticed in later stages of lactation in cow. The smaller size fat globules in the milk are associated with greater surface area and higher phospholipids content. The phospholipid content is an important factor in the development of brain and nervous tissues and plays a vital role in the fat absorption and digestion. The smaller size of fat globules had less coagulative properties and its leads to better digestion for infants and elder people (Kulkarni and Dole 1956). In the present result, the increased smaller size fat globules was noticed in late lactation because of higher concentration of long chain fatty acids and negative energy balance in early lactation and positive in late lactation and also the volume of membrane material is lower in early and mid-lactation.

Data of milk SCC on experimental animals are represented in Table 3. The overall milk somatic cell count content was fairly comparable ( $>0.05)$ between the Attappady Black and Malabari goats and also between the two breeds in weeks 1, 4, 7 and 10 of lactation stages. But it differed significantly $(p<0.01)$ within the both breeds of various lactation stages. The highest SCC (cells/ml) was observed in $10^{\text {th }}$ week $(122100 \pm$ 23654.81) and $16^{\text {th }}$ week $(123800 \pm$ 26713.20) of lactation in Attappady Black and Malabari goats respectively. The overall SCC of Attappady Black and Malabari goats were $71683.33 \pm 8885.58$ and $83466.67 \pm 8398.80$ respectively. This value of SCC was lower than the reference value of $1 \times 10^{6}$ suggested by Scruton (2010). In contrary to present findings, Rota et al., (1993) who reported the mean somatic cell count $\left(10^{6} / \mathrm{ml}\right)$ of the verata goats were $1.92 \pm 0.142$. Similarly, Das et al., (2000) observed that the SCC $\left(10^{6} / \mathrm{ml}\right)$ of multiparous cross bred goat milk ranged from $8.04 \pm 0.49$ to $15.18 \pm 3.11$ and Ying et al., (2003) reported the average SCC $\left(10^{3} /\right.$ $\mathrm{ml})$ of Sannen and alpine goats were $679 \pm$ 1378 and $746 \pm 1096$ respectively which was higher than the present findings. The milk somatic cell count of Attappady Black goats during weeks $1,4,7$ and 10 of lactation were represent in Table 3. The milk SCC was differ significantly $(\mathrm{p}<0.01)$ within the breeds of various lactation stages and there is no significant difference between the breeds in weeks $1,4,7$ and 10 . The findings were in accordance with Wilson et al., (1995) who reported the SCC had a significant $(\mathrm{p}<0.01)$ difference on stages of lactation. Similarly, Paape et al., (2007) reported the SCC had significant $(\mathrm{p}<0.01)$ difference between the stages of lactation and they observed the highest value of SCC was in end stage of lactation. The SCC observed in the native breeds is lower than those crossbred goats. This might be due to the more udder capacity of crossbred goats leading to high stress compared to the native breeds. In the present study, SCC increased with lactation progress (late lactation) regardless of whether the goat is infected or not. This might be due to excessive desquamation of epithelial cells in a small volume of milk in late lactation.

In conclusion the average smaller size milk fat globules and increased smaller size fat globules proportion was noticed in later stage of lactation in both indigenous goat breeds. These characteristics of the fat globules can affect the milk quality and digestive parameters. In addition, the smaller size fat globules may use for cheese making and increasing the quality of cheese as well as it is beneficial for human health in terms of lipid and protein content of milk. Due to the apocrine nature of milk secretion, somatic cell counts in goat's milk naturally include a high 
percentage of non-DNA containing cytoplasmic particles that largely distort the well-accepted relationship between SCC and the level of udder infection that occurs in cow's milk. In goat's milk the SCC is extremely variable and generally much higher than in cow's milk. Factors such as stage of lactation, oestrus, method of milking, season, breed and lactation number may influence the SCC. So more studies are still require for factors affecting the milk quality and quantity as well as exploring the use of goat milk for human consumption.

\section{References}

Attaie, R. and Richtert, R.L. 2000. Size distribution of fat globules in goat milk. J. Dairy. Sci.83: 940-944.

Berry, E. and Broughan, J. 2007. Use of the DeLaval cell counter (DCC) on goat's milk. J. Dairy. Res.74: 345 - 348.

Bravoa, O.G.B., Cháveza, A.J.G., Sahagúna, C.A.A., Montaldob, H.H., Shepardc, L. and Posa, M.V. 2013. Losses in milk yield, fat and protein contents according to different levels of somatic cell count in dairy goats. Small. Rum. Res: 113(3): 421-431

Carriquiry, M., Weber, W.J., Dahlen, C.R., Lamb, G.C., Baumgard, L.H. and Crooker, B.A. 2009. Fatty acid composition of milk from multiparous Holstein cows treated with bovine somatotropin and fed n-3 fatty acids in early lactation. J. Dairy. Sci. 92: 48654875.

Cinar, M., Serbester, U., Ceyhan. A. and Gorgulu, M. 2015. Effect of somatic cellcount on milk yield and composition of first and second lactation dairy cows. Ital. J. Anim. Sci. 14: 105-108.

Das, M. and Singh, M. 2000.Variation in blood leucocyte, somatic cell count, yield and composition of milk of crossbred goats. Small. Rum. Res. 35: 169-174.

DeLaval. 2005. Instruction booklet http://www.delaval- us.com/products/milking equipment/ milk quality/DCC/default.htm.

DeVliegher, S., Barkema, H.W., Stryhn, H., Opsomer, G. and DeKruif, A. 2005. Impact of early lactation somatic cell count in heifers on milk yield over the first lactation. Journal of Dairy Science., 88: 938-947.

Droke, E. A., Paape, M.J. and Di Carlo, A.L. 1993. Prevalence of high somatic cell count in bulk tank goat milk. J. Dairy. Sci. 76: 1035 - 1039.

Dulin, A.M., Paape, M.J., Schultze, W.D. and Weinland, B.T. 1982.Effect of parity, stage of lactation, and intramammary infection on concentration of somatic cells and cytoplasmic particles in goat milk. J. Dairy. Sci. 66: 2426 - 2433.

George, B. 1981. Properties of milk fat of crossbred goats. M.V.Sc thesis, Kerala Veterinary Animal Sciences University, Pookode, 66p.

Hoda, M. and El-Zeini. 2006. Microstructure, rheological and geometrical properties of fat globules of milk from different animal species. polish journal of food and nutrition science. Pol. J. Food Nutr. Sci. 15/56(2): 147-154.

Jenness, R. and Parkash. S. 1971. Lack of a fat globule clustering agent in goats' milk. J. Dairy Sci.54:123-126.

Keenan T.W and Mather I.H. Milk fat globule membrane. 2002, in: Encylopedia of Dairy Sciences (H. Roginski, J.W. Fuquay, P.F. Fox). Academic Press, London, pp. 1568 - 1576.

Kuchroo, T.K. and Narayanan, K.M. 1977. Effect of stage of lactation on distribution of fat globules and phospholipids content of milk.Indian J. Dairy. Sci.30(2): 99-104.

Kulkarni, P. S. and Dole.K. K. 1956. Investigations in viscosity of milks. Indian J. Dairy Sci. 9: 68-79.

Narangerel, C., Narangerel, M., Batsukh, T.S., Munkhjargal, B., Erdene, A.B. and Dorjsuren, T.S. 2016.Characterization of Mongolian Goat Milk. J. Exp. Food. Chem.2: 120. 
Paape, M.J., Wiggans, G.R., Bannerman, D.D., Thomas, D.L., Sanders, A.H., Contreras, A., Moroni, P. and Miller, R.H. 2007. Monitoring goat and sheep milk somatic cell counts. Small.Rum. Res. 68: 114125 .

Parkash, S. and Jenness, R. 1968. The composition and characteristics of goat milk: A review. Dairy Sci. Abstr.30: 6787.

Petlane, M., Noor, R.R. and Maheswari, R.R.A. 2012. Relationship between somatic cell counts, mastitis, and milk quality in Ettawah grade and PESA goats. Agric. Techn. Biol. Sci. 10(6): 607-613.

Puri,B.R., Lakhanpal, M.L. and Gupta, S.C. 1952. Determination of size distribution of fat globules in milk by the application of Stokes' Law. Studies in physicochemical properties of milk. Indian J. Dairy Sci. 5: 189-199.

Rangappa, K.S. 1964. Studies fat globules in milk. Indian J. Dairy. Sci. 17: 95-96.

Reneau, K. 2001. Somatic cell counts: Measures of farm management and milk quality. National Mastitis Council Annual Meeting Proceedings. pp. 29 37.

Rota, A.M., Gonzalo, C., Rodriguez, P.L., Rojas, A.I., Martin, L. and Tovar, J.J. 1993. Effect of stage of lactation and parity on somatic cell counts in milk of verata goats and algebraic models of their lactation curves. Small. Rum. Res. 12: 211-219.

Schultz, L.H., Broom, R.W.,. Jasper, D.E..Berger, R.W.M., Natwke, R.P., Philpot, W.N., Smith J.W. and Thompson, P.D. 1978.Current concepts of bovine mastitis. 2nd Ed., National Mastitis Council, Washington, DC, USA: 6-9.

Scruton, D. 2010. Guide to crisis management of somatic cell counts in goats. $\left(2^{\text {nd }}\right.$ Ed.).Vermont Agency of Agriculture, Food and Markets. U.S. 2p.

Stahy, R.M. and Argaman, N.A. 2014. The relationship between size and lipid composition of the bovine milk fat globule is modulated by lactation stage.Food. Chem.145: 562-570.

Venkatachalapathy, T. R. and Iype, S. 1997. Fat globule size and distribution in milk and iodine value of milk fat of Vechur cattle of Kerala. Indian J. Anim. Sci. 67(10): 910-912.

Wilson, D.J., Stewart, K.N. and Sears, P.M. 1995. Effects of stage of lactation, production, parity and season on somatic cell counts in infected and uninfected dairy goats. Small. Rum. Res. 16: 165-169.

Yarabbi, H., Mortazavi, A., Mehraban, M. and Sepehri. N. 2014. Effect of somatic cells on the physic-chemical and microbial properties of raw milk in different seasons, International Journal of Plant, Animal and Environmental Sciences, 4(3): 289-298.

Ying, C., Yang, C.B. and Tayhsu. J. 2003. Relationship of somatic cell count, physical, chemical and enzymatic properties to the bacterial standard plate count in different breeds of dairy goats. Asian-Aust. J. Anim. Sci. 17(4): 554559.

\section{How to cite this article:}

Sudharsan, M., A. Kannan, K. S. Anil, Justin Davis, K. Ratha and Dhinesh Kumar, S. 2020. Milk Fat Globule Size, Distribution and Somatic Cell Count of Indigenous Goat Breeds in Kerala. Int.J.Curr.Microbiol.App.Sci. 9(08): 2528-2535. doi: https://doi.org/10.20546/ijcmas.2020.908.290 